\title{
Erga Heller
}

Kaye Academic College of Education, Be'er Sheba, Israel heller@kaye.ac.il

\section{From Street Girl to Roman Goddess: The Creation of Multiple Visual Alices from 1858 to 1872}

Izvorni znanstveni rad / original research paper

Primljeno / received 8. 4. 2015. Prihvaćeno / accepted 11. 12. 2015.

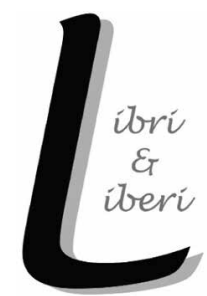

Victorian representations of childhood are found in a wide variety of cultural texts, from literary descriptions to visual images. Alice's Adventures in Wonderland by Lewis Carroll (1865) is no different in this sense. However, Alice's character is one of the first of its kind to behave as a cross-media figure, thus becoming a fantasy literature heroine as well as a popular cultural icon. This paper focuses on Alice's artistic representations in three forms: (a) Lewis Carroll's verbal art; (b) the photographic prints of the "real" Alice Liddell taken in 1858 and 1872 by Carroll and Julia Margaret Cameron respectively; and (c) the visual illustrations by Carroll and by John Tenniel (1864 and 1865, respectively). The aim of the paper is to discuss whether Alice was ever a "real" Victorian girl, by examining her multiple representations in the given corpus. It also aims at analysing Alice's visual characteristics in order to reveal Alice as a visual concept of her times.

Keywords: fantasy literature, Alice's Adventures in Wonderland, illustration, photography, cross-media, visual culture, Julia Margaret Cameron

\section{Introduction}

Victorian representations of childhood are found in a wide variety of cultural texts, in literary descriptions and in visual images. Lewis Carroll's Alice's Adventures in Wonderland (1865) includes both textual and visual representations of a child, Alice. The book was a nineteenth-century equivalent of a bestseller, 
selling - according to Carroll - more than 70,000 copies (Cohen \& Wakeling 2003: 237) and has since achieved canonical status. Even today, 150 years after it first appeared, it is still being re-printed, re-translated, and adapted to popular media. Over a period of 150 years, Alice's Adventures in Wonderland has engendered dozens if not hundreds of sequels, films, literary references, animated versions, graphic novel adaptations, spinoffs, and even a scientific-didactic novel (Alice in Quantumland by Robert Gilmore, 1994). Recently, a retelling of the Alice story has been published by Gregory Maguire (involving Darwin, and not one but three missing children in Wonderland), knowingly entitled After Alice (2015, William Morrow/HarperCollins). Early and late, it has figured in TV series, from the first season of Star Trek (1966, episode 15), to episodes of The Simpsons (2003, season 14, episode 22; 2013, season 24, Treehouse of Horror). While the majority of these works are published and produced in English, French, Chinese and Japanese, they also appear in more esoteric languages and cultures. For Alice's Adventures in Wonderland's $150^{\text {th }}$ anniversary, Joan Braman translated the first modern Yiddish version, Di Avantures fun Alis in Vunderland, published in 2015 (Evertype Publishing). Although Yiddish is a gendered language, Braman uses the "real" gender - according to the original text - in order to be true to Carroll's plot (2015: vii). Alice in Wonderland and its adaptations have long since outgrown their initial Victorian contexts, to become part of a worldwide Alice culture.

But the popular "Alice" icon (Tenniel's) as the sole source of this culture is false; from the very start, indeed, at the very moment of composition, the image of Alice held more than one meaning, and these meanings are still being explored today. This paper sets out to analyse the early construction and establishment of multiple Alices, in order to question whether and how "Alice" represents a model of Victorian girlhood, and to indicate the complex basis upon which the contemporary Alice culture is founded. The paper focuses on three main sources:

- in literature, on the manuscript of Carroll's 1864 "Alice's Adventures Under Ground" and on the book Alice's Adventures in Wonderland (1865 [dated 1866]);

- in photography, on the photographic prints of Alice Liddell as a child by Carroll and as an adult by Julia Margaret Cameron, dated 1858 to 1872;

- and in illustration, on the original illustrations by Carroll for the 1864 manuscript and John Tenniel's illustrations for the published edition.

An examination of the literary and visual images of the first Alices, from 1858 to 1872 , can reveal the differences in approach and aim of representation by Carroll, Tenniel and Cameron. 
Illustrations are visual images that adapt, translate, or interpret the verbal text into a non-verbal set of signs, in a process of inter-semiotic translation. It is therefore crucial to establish a "source text" to which the visual adaption refers. When the transfer is between two different art forms, such as prose fiction and illustration, the process of inter-semiotic translation must be selective, that is, must necessarily emphasise only certain words and specific narrative elements (Pereira 2008: 107-111).

Although there is no doubt that Carroll's story acts here as a lingual "source text" - it was clearly the first written - Alice's Adventures in Wonderland is not the first text of the cultural Alice series. Carroll photographed Alice Liddell (his model for the literary Alice) at least seven years before the book was published. By the time Alice's Adventures in Wonderland was published, Lewis Carroll - the alias of the mathematician Charles Dodgson of Oxford University - was already known as a remarkable amateur photographer. He has been called "the most outstanding photographer of children in the $19^{\text {th }}$ century" (Alexander 2006: 3 ), though this may be disputed. Thus, it is possible that Alice's visual image was created years before her literary narrative was fully designed, as was suggested by Carroll's nephew in his 1898 biography (4). And if this is true, the first representation of Alice is not that of the literary heroine, but of the young Alice Liddell captured through Carroll's lens. Therefore, my main aim is to sort and analyse Alice's visual characteristics, from 1858 to 1872 , in order to study the Alice series as a visual concept of her times.

\section{Alice's multiple portraits}

It may be, as Robson (2001: 142) suggests, that Alice's curiosity and sense of adventure, seen as an anomaly in female behaviour in the Victorian age, contribute to her ongoing popularity as a cultural heroine; whatever the case may be, Alice's contemporary cultural references prove that Alice as icon is still relevant although the character was created in the Victorian era (Manning 2011: 155). There are many visual representations of Alice. The most enduring, canonical illustrations are those by John Tenniel for the 1865 book. Tenniel's illustrations show a beautiful girl with fair hair and light eyes. She wears the "uniform" of a Victorian girl, a pleated, belted dress, a pinafore, long white stockings, and buckled black shoes. Tenniel's illustrations were approved by Carroll, although he himself, who knew the original Alice personally, portrayed her in the handwritten 1864 edition closer to her real looks, with dark hair and eyes. Walt Disney's (1951) visual interpretation of fair Alice is a blond with blue eyes. In Tim Burton's Alice in Wonderland (2010) Alice (the actress Mia Wasikowska) is a blond young woman with brown eyes, who gets 
lost during a Victorian garden party. From the second part of the nineteenth century to the second decade of the twenty-first, then, the image of Alice has evolved from black-and-white illustrations to intricately imagined cinematographic icons. Alice has other celebrated visual interpretations, such as the Swedish-Finnish children's author Tove Jansson's (1966) illustrations of a blond girl with brown eyes, or the Spanish artist Slavador Dalí's (1969) surrealistic prints.

Lewis Carroll was aware of the importance of drawings in children's books (Hancher 1985: 26; Cohen \& Wakeling 2003: xxiii), and also had an eye for composition due to his photographic expertise (Manning 2011: 155, 160). There are only a few artistic photographs of Alice Liddell (1852-1934), some by Lewis Carroll, and some two dozen by Julia Margaret Cameron. Photographs of young girls in various forms of dress and undress became a common late-Victorian genre, with the growing popularity of photography and the interest in childhood as an age of innocence. In this context, Alice Liddell was more than a muse for Carroll's book (Brooker 2004: 171). She was an exemplar, an almost allegorical figure of innocent, pre-socialised girlhood, as illustrations and photographs show, hence she was not the common Victorian sexual counterpart (Gilbert and Gubar 2000: 7). In her journey across decades and media to the twenty-first century, her image constantly questions and articulates various meanings ascribed to being a child and/ or a young woman in society. Like other fantasy characters, Alice stepped out of the literary illustrations to become a global phenomenon (Heller 2014: 174). But Alice is unique in being a children's literature heroine whose fictional representation merges with her real life identity.

Of the many Alices, dark and fair, adventurous and shy, young and adolescent, one may wonder who the most Alice-like figure of them all is. Lewis Carroll is the original author and first illustrator, as well as Alice Liddell's photographer, but despite this - or especially because of it - this "source" is already multiple. In other words, the verbal text is not the "source text", and not all visual versions are interpretations of the verbal description. Furthermore, in Gilles Deleuze's words, the literary Alice is a "present Alice", meaning that Alice's physical being is true only at a certain point in space and time (Williams 2008: 29). According to Deleuze, in the text of Alice's Adventures in Wonderland there are many Alices, and in any given episode one Alice may change into another, but each one is a pure representation of a single moment in the text; therefore her representations are not paradoxical, although there are many Alices (Deleuze 1969: 9). 


\section{A bright palette}

Catherine Robson suggests that Lewis Carroll used several Alices, or "others", as his literary model, all of them aspects of Alice Liddell at different ages. Carroll's writing was a response to the "real" Alice Liddell's physical and mental development, while his photographs of her remained frozen in time, focusing on the childish representation. Hence his creative textual power was engaged to present Alice as everything and its opposite simultaneously, and Alice in Wonderland is the paradoxical result of his ambivalence (Robson 2001: 140-141).

Even if we do not accept Deleuze's or Robson's claims, Carroll himself shows two different Alices in his original manuscript of "Alice's Adventures Under Ground", which he gave as a Christmas present to Alice Liddell in 1864. One is the literary Alice who "had not a moment to think about stopping herself" (Carroll 1864: 2), curious, active, surrounded by golden ideals: the adventure was told "All in the golden afternoon" of a perfect Victorian day (prefatory poem to the published version), when Alice discovers a golden key and a "golden scale" (6); while the second Alice is illustrated (Fig. 1). In the thirty-seven illustrations of the manuscript, Carroll paints Alice's hair and eyes black, looking like Alice Liddell, unlike Tenniel, who uses black only for the contour-line of Alice's hair and eyes, hence implying fair hair and light eyes.

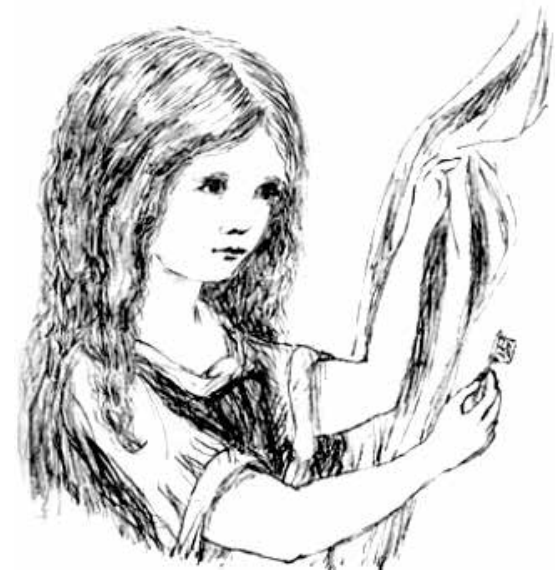

Fig. 1. Alice in Lewis Carroll's original manuscript, $1864 .{ }^{1}$

Sl. 1. Alica u izvornome rukopisu Lewisa Carrolla, 1864.

1 The manuscript is in the British Library Collection, available at $<$ http://www.bl.uk/\#>. It is in the public domain. 
Carroll completed the manuscript for publication by 1865, and John Tenniel did the illustrations under Carroll's supervision. In Tenniel's hands, Alice became a golden child, suiting the Victorian preference for golden - blond - hair (Ofek 2009: 25). This change of appearance turned Alice into a visual image of purity based on her golden look (Sandner 1996: 10). The key for understanding this physical change is found in Romantic symbolism.

When Carroll photographed a series of compositions, in the middle of the 1850s, representing Liddell as a street child begging for money, he used a familiar feminine image of a street beggar (Sandner 1996: 40). Liddell is underclassed, underestimated, sexualised by her artificial pastoral posture (Armstrong 2002: 218-219).

In the best known photograph from this series, The Beggar Maid (1858), ${ }^{2}$ Carroll places his young model in the front, holding her open hand close to her chest, gazing directly at the viewer (Spence 2013: 325; Winchester 2011: 5-6). Her bare feet form the base line of his centred composition. The girl's white rags are ripped, yet they are as clean and as tidy as a fairy's gown. The young girl is standing before a corner of an old mossy stone wall, her head slightly tilted, unsmiling, perhaps impatient, or speculating on the photographer's purpose, as if waiting to see her audience's response. Despite the subject matter, Carroll avoids the social meaning of being a poor child, focusing on the contrast between the dark old wall and the young girl dressed in white, her posture, her otherness, drawing attention to her delicacy. The photograph is not eroticised, but it does invite the viewer to enter into a sensual - not a sexual - fantasy, meaning to enter voluntarily into an imagined world divided from the outer world by plants and walls in the background. Furthermore, according to Carolyn Steedman (1998: 139), for Carroll, the concept of "being a child" is a feminised concept, since girlhood is the essence of a quest of lost happiness. Thus, The Beggar Maid is as much part of this quest as is Alice's Adventures in Wonderland.

Although the image of a little beggar girl has its source in Romantic and PreRaphaelite imagery, it could not contain the contradictions of the literary Alice: polite but bad mannered, carefree but troubled, surrounded by beauty but creating chaos, etc. While Liddell can be shown as a street girl, literary Alice must be depicted as a pure being, a dream child in a fantastic place that no men may enter (Steedman 1998: 147). These dichotomies (fair/dark; childhood/adulthood; girl/man; divine/ earthly) are the key for understanding images of Alice, from Tenniel's on.

2 Carroll's The Beggar Maid (1858) can be found in the Metropolitan online collection: $<$ http://www.metmuseum.org/collection/the-collection-online/search/283092> (retrieved on 1.11.2015). 


\section{The secrets of the "big" metamorphosis}

Young literary Victorian heroines are often described as non-consumers (Coar 2012: 49). They depict the ideal of an idle and delicate identity: passive, beautiful, seen but not heard. To be represented, Alice must partake of this identity, but her changes - physical and mental - lead her to contradict these characteristics. Thus, the opening of Chapter One of Alice's Adventures in Wonderland presents Alice as beautiful and passive. She drowses in a field of daisies - an image of softness and vagueness. This Alice is loving and trustful, characteristics which make her delightful (Driscoll 2002: 43). But the seemingly delightful Alice is actually bored, while her golden double is burning with curiosity and is full of action. Meditative and bored, Alice stays dreaming next to her proper older sister, who reads a book "with no pictures or conversations in it" (Carroll 1970: 30). Catherine Golden suggests that the sister's book is an allegory for Victorian education which Alice attacks; Alice's choice is to create her own imagined world instead of reading a boring book (2003: 191). The active Alice enters Wonderland by making her own choices, and takes a risk by drinking from an unmarked bottle. Eating and drinking change Alice's size, physically and symbolically, and her transformation, physical and mental, coincides with the beginning of her adventure.

Successful negotiation of Wonderland is often signalled by size change, and such change requires and promotes size change. From the frustrations in Chapter Two to the Caterpillar's advice to the successful escape from the trial in Chapter Twelve, Alice grows to understand her place, her stature, and always through food or drink, suggesting a connection between eating and active being. Her "telescopic" movement in space relates also to transportation through time, as Alice is forced to "grow up" at an unnatural pace. Alice's eating and drinking episodes are presented as dangerous occasions, yet brimming with energy, often leading to insults by herself and by male figures such as the Mad Hatter or authoritative figures such as the Queen of Hearts.

The contradictions within literary Alice's behaviour are augmented by her image by Tenniel. He gives her a naïve look, emphasising her primness and innocent fairness. But more subtly, Tenniel presents her in a non-proportional way in most of his illustrations. Often her head is too big in proportion to her body, sometimes her limbs are too large in comparison to background objects, sometimes she is too small, suggesting a caricature, especially in situations where she is portrayed with other caricaturised characters, such as the Mad Hatter and the Queen of Hearts, or when portraying the results of her eating or drinking. In almost all the illustrations Tenniel draws her in profile and half-profile, suggesting an activeness and determination that are at odds with her "airiness". 
In Alice's Adventures in Wonderland, Alice's image is very different from Liddell's image as a Beggar Maid (Carroll 1858). Wandering in Wonderland, Alice is full of energy - very inappropriate feminine behaviour according to Victorian norms - in contrast to the Romantic image of the poor girl. The contrast between the two images could not be greater, yet they are both young Victorian girls, both Alices.

At the beginning of Chapter Two, Alice completes her change from a delicate girl into her new being, rather the opposite of the emblematic Caterpillar in Chapter Five, that turns into a delicate, airy butterfly. Alice's description of herself altering "like a telescope" (Carroll 1970:30) after drinking and eating is retained by Tenniel's illustrations which depicted her awkwardness at being cramped, stretched, and in general too big for her surroundings (Carroll 1970: 36). Alice is not ashamed of her size, but of her childish behaviour which does not fit her new "big" appearance. Tenniel creates the reader's first visual introduction to being "big" already in the frontispiece, where the trial scene with the Queen of Hearts from the concluding chapter is depicted. Here, being "big" is being old and fat. The telescopically stretched Alice is the opposite of the Queen of Hearts. She is young, thin, and tall while the Queen is old, fat, and short; Alice's eyes look to her left while the Queen's eyes look to her right; Alice's hands are open, while the Queen's arms are folded on her chest; Alice has a long giraffe-like neck, while the Queen has no neck at all. Yet both Alice and the Queen have the same triangular heads, perhaps to suggest their common absurdity, one a "big person" who behaves capriciously, the other a "small" one who grows too fast (Fig. 2).

As Alice wanders through puzzles, conundrums, and paradoxes that constitute Wonderland, she is neither a typical Victorian girl nor a Victorian adolescent. Her leaps to social and scientific extremes enable her - and the reader - to study the nature of her spontaneous search. On the one hand, her search is for identity, a psychological self-inspection that can be found in stories for girls (Driscoll 2002: 42). On the other hand, her search can be read as a much wider cultural quest, questioning social norms, axioms and rules. From this perspective, Alice's eating episodes not only change her physically, they also engage her in speculating about intellectual and social behaviours. Thus, her metamorphoses are themselves an embodied aim as she studies the new territory of Wonderland. 

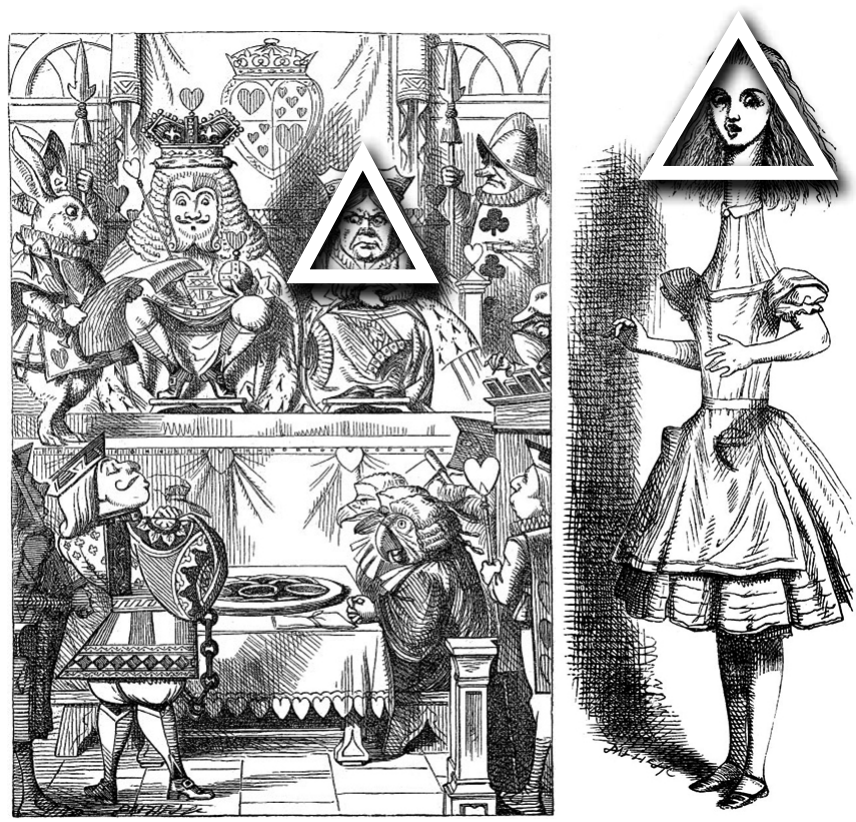

Fig. 2. Tenniel's illustrations reveal the meaning of being "big". 3

SI. 2. Tennielove ilustracije otkrivaju što znači biti ,velik“.

\section{Challenging the natural order of things}

In Chapter One the readers encounter an impossible process: Alice "grows" smaller and smaller. Alice's success in fulfilling her desire depends on challenging her passive being. She must act, must take the initiative, in order to free herself from her fears. Hence she must find the way to return to her proper body, and "grow smaller" (Carroll 1970: 33) into her child-being in order to develop properly.

"Grow smaller" is an oxymoronic figure, which is based on physical size and implies the natural growing process (big=grownup / small=child), and cultural concepts ( solid=mature male / delicate=young female). Alice is naturally growing up, hence losing her idle - meaning passive - features. But the fantastic environment of Wonderland enables Alice to grow - meaning to evolve - faster in all directions: (1) to be small and idle and delicate, a feminine concept indicating passivity; (2) to be small and adventurous, a hybrid idea that converges feminine and masculine qualities; (3) to be big and delicate, another new hybrid idea by Carroll that contains feminine and masculine qualities; (4) or to be big and adventurous, a masculine concept.

\footnotetext{
3 John Tenniel's illustrations of the Alice books are in the public domain, as are the other illustrations
} reproduced in this paper. 
Carroll's photographs of Alice Liddell were taken when she was a child. As a photographer he took dozens of pictures, including nudes, of his colleagues' and friends' children. The common explanation is that Carroll, as an amateur photographer, focused on the perfection of the "littleness" of his young models (Driscoll 2002: 43). This explanation proposes a one-sided photographic view that suits the Victorian or Pre-Raphaelite visual aesthetics, and can explain why Carroll preferred young girls and baby boys: they had fairy- and putty-like characterisations. The new photographic technology of the end of the $19^{\text {th }}$ century enabled artists to present their subjects with soft light, to blur margins, and use other procedures that contributed haziness and a softening to their compositions.

Tenniel's illustrations that appeared in the first, 1865, edition fitted Carroll's aim of using the drawings as supplementary and illuminating texts (Hancher 1985: 98). Tenniel continuously shapes and reshapes Alice. In doing so, he abandons the golden proportions in favour of the oxymoronic narrative. Tenniel's Alice is designed to fit a non-proportional world. At various points in the narrative Alice is pictured smaller than a mouse and a puppy, roughly as big as a caterpillar and a cat, taller than a tree or than a courtroom. While Carroll's verbal text uses the oxymoron "grow smaller" in a social context, Tenniel's drawings imply revolutionary thoughts about the natural order of things. Even though Tenniel's illustrations are largely based on Carroll's original manuscript (75\% according to Hancher 1985: 28), it is important to note the differences, especially in light of the "grow smaller" oxymoron. Tenniel often chooses more dramatic and empowering perspectives than Carroll did in his 1864 manuscript, by using the dynamics inherent in the cognitive opposites "grow" and "smaller". Tenniel transforms "grow" into nonproportional larger objects on one side of the composition, and "smaller" Alice on the other side, and vice versa. Due to the diagonal line that connects the larger and smaller subjects, Tenniel succeeds in creating his oxymoronic view, echoing and extending Carroll's text.

\section{Knowledge and wandering hair}

The word "know" appears fifty-two times in Alice's Adventures in Wonderland, mostly in the context of Alice's study of the world of Wonderland and her interactions with other characters. However, the word "knowledge" appears just once, in the first chapter, when Alice calculates the depth of the rabbit hole, based on her subjective ongoing experience. "Knowledge" is referred to as a collection of "several things" that are taught in lessons at Alice's school. The narrator interrupts Alice's monologue and addresses the reader directly (Carroll 1970: 28), revealing 
her private thoughts and manifesting her lack of knowledge ("Alice had no idea what Latitude was, or Longitude either, but thought they were nice grand words to say"; Carroll 1970: 28). With this interruption, the narrator implies his and our superiority over Alice, for she has little real knowledge; for a brief moment the reader may see Alice as an imposter or as a stupid little girl. But, of course, she is neither the one nor the other. Down in the rabbit hole, upper world knowledge turns out to be wrong or useless. Curious Alice never stops questioning and studying her strange new environment, like an explorer striving to make sense of a place in which the knowledge with which she came cannot explain the phenomena she experiences. She builds her ad hoc knowledge out of active field interviews and field experiments. Her learning method is not passive or axiomatic. Here Alice starts her transformation, first mentally, by questioning the world, and only then by adding the physical changes through the eating and drinking episodes. Her initial mental change transports her from a passive position - an obedient young girl sitting near her sister on a bank, a Victorian pupil learning moral maxims and pieces of advice by heart - into an observant, analytical, and imaginative being. The crowning experience, powerful and cathartic, comes at the end of the story. When the Queen at the trial pronounces "Off with her head!", Alice says "Who cares for you?... You're nothing but a pack of cards!" (Carroll 1970: 187), and she wakes out of Wonderland as all the cards rise in the air to attack her, to find herself safely on the bank next to her sister. Alice has gained new knowledge of herself and of her position in the world.

Middle-class Victorian women and girls were supposed to cultivate only domestic knowledge, while wide-ranging knowledge was a male preserve (Gilbert and Gubar 2000: 4; Casteras 2012: 117, 143). Alice's Adventures in Wonderland goes against this prejudice by placing a powerful, enabled girl as heroine. Alice's study of her new environment is the mirror image of so-called masculine abilities; and yet, it exists only in a dream.

However, within Wonderland, "to know" is to build basic knowledge out of autodidactic studying and wandering, which are child-like behaviours. Alice's wandering in Wonderland is a way of reaching the limits of that world. By wandering Alice not only examines the world but also interrogates herself, her mental world, her fears and preconceptions, and examines her social status. Thus, wandering is a test no less than it is a quest, an aspect of which has endured in subsequent representations of Alice.

At the end of the story, in an abrupt change of focus, Carroll describes Alice's sister's thoughts. She has a "dream" of Alice's "bright eager eyes [...] [she] could hear the very tones of her [Alice's] voice, and see that queer little toss of her head, 
to keep back the wandering hair that would always get into her eyes" (Carroll 1970: 190). Alice's hair is allowed to wander as a reminder of the waywardness, wildness, and freedom of Wonderland, qualities that Alice shares, too. That her hair will "always get into her eyes" signals not obscurity but a different, less conservative vision. Given Carroll's undoubted awareness of contemporary Pre-Raphaelite poetry and painting, the wandering hair may also be an intertextual reference to Pre-Raphaelite hair imagery. The loose, flowing locks of Pre-Raphaelite female figures mocked Victorian women's hairstyle fashions, which reflected their anxiety towards being on show (Ofek 2009: 29, 218). In the manuscript (1864), Carroll draws Alice with her hair dark, abundant, and unfettered. In the book (1865), he uses the wandering hair to hint at the restricting norms. Thus, at the end of her adventures and changes, as her sister sends Alice to "run in for [her] tea", she still manages to be a pure golden child, combined with new-found freedom and knowledge.

\section{The act of metamorphosis and evidence of secret knowledge}

The common feature of the multiple Alices, according to Deleuze, is their knowledge. Deleuze believes that the power of the literary Alice is found in the fact that no matter how many times she changes, and no matter how many times she enters a new stage or experience, all the things she goes through and the creatures she meets are actually a single event, one "Adventure", since the narrative is about the process of gaining solid knowledge (Deleuze 1969: 11). Alice seeks knowledge in order to reveal the hidden secrets of Wonderland (19). But in reading Alice's Adventures in Wonderland from a Victorian point of view, the reader may find that the desire for such knowledge is unacceptable for a young girl; it is a social challenge that may destroy the order of things, and this is the psychologically realistic motivation for the Queen of Hearts' wish for Alice's death.

In the 1870s, the photographer Julia Margaret Cameron added several more Alices. The major difference between Carroll's and Cameron's attitudes toward photographic portrayals is not their variety of themes, which are relatively close, but the fact that Cameron had no artistic or academic reputation to lose. She was a devoutly religious mother of six, in a family that had lived in India for generations. She came back to live in England upon her husband's retirement, and at some point was given her first camera as a present (Cox 2002: 5). At the time there were few expectations of a woman using the new technological invention, the camera. Cameron was expected simply to amuse herself with it (6). However, the camera brought her enormous freedom, artistic and other, and she became one of the most 
important photographers of her time, photographing, among others, Alfred Lord Tennyson and Sir John Herschel.

Cameron's prints are the work of a gifted artist who used the Romantic tropes in a slightly different manner from contemporary male photographers. Part of her innovative attitude was to show the personality of her models, the inner self of the photographed persons (Marsh 2003: 119). Using soft focus, close-ups, and bright light she created a softer atmosphere (Ford 2003: 54). She created fictional scenes that were supposed to be naïve and pure, that is, were supposed to be emptied from "knowledge", but instead they were empowered by her feminine revolutionary point of view. Like Carroll's, whose Alice is within the literary tradition of the questing male hero, from Ulysses on, Cameron's narratives of her adolescent model, Alice Liddell, make her (look) like a Goddess; and she does this, we should note, only with the power of light and close-up technology. This re-invention and re-positioning is evident also in Carroll's intention in his illustrations for "Alice's Adventures Under Ground" and in his directions to Tenniel - to show the familiar world from an unexpected perspective. Hence in the summer and the fall of 1872 , Cameron photographed a series of eleven portraits of Alice Liddell mostly as Classical goddess (Pomona, Ceres) or allegorical figure (Alethea) (Cox and Ford 2003: 175-176).

\section{Alice as a grown-up}

In Latin, the name Pomona is derived from pomum - an orchard fruit. Pomona was a favourite erotic subject of artists from the seventeenth to the nineteenth centuries. Her artistic attribute was a peach, the ultimate orchard fruit in visual imagery. But according to Ovid in Metamorphosis, book XIV, the nymph Pomona becomes the victim of the lust of Vertumnus - the god of seasons and plant growth. After her refusal to accept his obsessive courting, Vertumnus turns into an old woman, and in that guise he kisses Pomona and talks her into returning his love, successfully seducing her in the end.

In the Pomona image, Cameron presents a close-up of Liddell in a faded white dress (Fig. 3). Cameron, like the Pre-Raphaelite painters, pays close attention to her sitter's hair. Although in many of her works Cameron uses hair and clothing to "envelope" and hide the female body (Marsh 2003: 124), in Pomona the wild wandering hair, the placing of hands, and the floral hints work deliberately to evoke the imagery of Carroll's The Beggar Maid (1858). Cameron's visual transformation of Liddell is complete, her measurements refined: Alice eventually and properly "grew bigger", from a beggar girl to a goddess. Cameron does this through her 


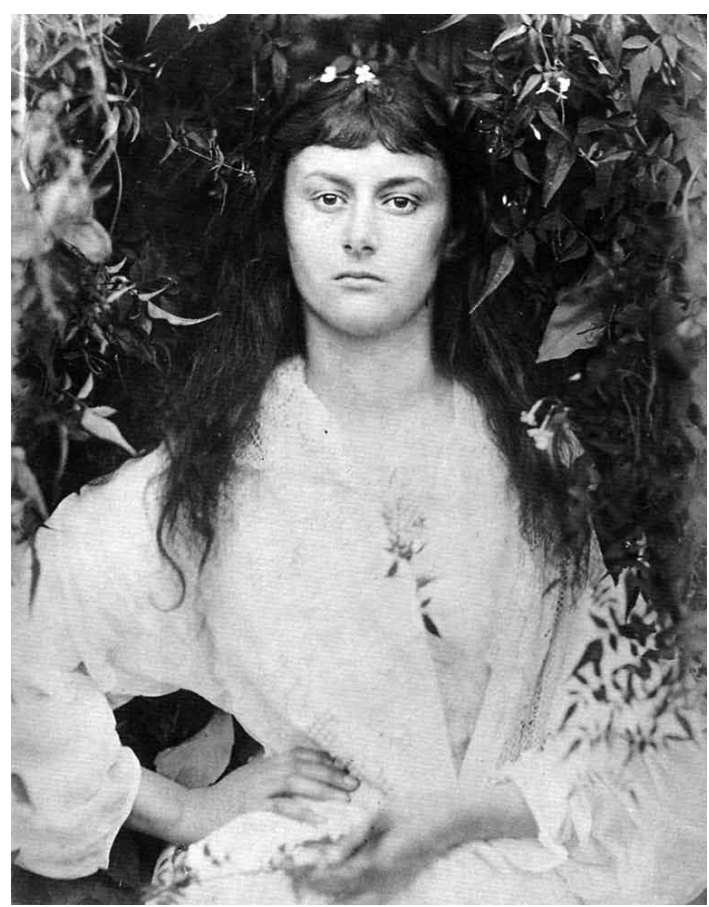

Fig. 3. Julia Margaret Cameron: Pomona (Alice Liddell as a young woman), 1872.

Sl. 3. Julia Margaret Cameron: Pomona (Alice Liddell kao mlada žena), 1872.

dialogue with Beggar Maid, as well as with Alice's Adventures in Wonderland, text and illustrations. For in Pomona, Cameron plays with the way the viewer apprehends Alice's size and proportions, just as Carroll and Tenniel do with Alice's body in Wonderland. Where Carroll "cut" Alice's portrait at the toes, Cameron cuts her below her waist. Alice's body fills the space entirely, the leaves of the background merging with her hair. But Cameron's Alice does not consume anything: it seems that her growing-up process has reached its peak.

Space and size are important features of nineteenth century photography, since they give a scientific and objective view of the world; in a way they measure the world (Meier 2009: 119). Alice Liddell, as a beggar and as Pomona, is used to measure the Victorian social world. Neither of those measurements is scientific, but they have a strong cultural basis. Carroll as an author and photographer, and Cameron as a photographer, show the uselessness of allegedly scientific measurements. It is useless to apply latitude and longitude in Wonderland; and Cameron transforms Liddell from a literary child-like character into the body of a goddess. The closeup composition enlarges Alice. In 1872, therefore, in the Pomona image, Alice of Wonderland stops changing in all directions, to emerge as an adult woman. 
Cameron's Alice in September 1872 (in Cox and Ford 2003: 175-176, 234, ill. 361) refers both to Carroll's The Beggar Maid (1858) and to Tenniel's 1865 illustrations presenting the disproportionally "grown" Alice, after consuming drink and cake. In Cameron's portrait Liddell looks directly at her viewer, like Carroll's beggar, but her posture is different: she holds a rose close to her chest with her left hand; her right hand - the begging hand in Carroll's picture - is left out of Cameron's composition. Although she is wearing white again, her clothes are perfectly arranged. A ribbon - like Tenniel's - is added to Liddell's dress. But two important features are changed: she is no longer bare-necked but wearing a rhombus-shaped pendant and her hair is made up and shiny. This portrait visibly represents the grown-up Alice. The impact on the viewer is not sensual or erotic, not delightful or enjoyable, but powerful.

\section{Conclusion}

It is not surprising to find visual similarities between the illustrated Alice in Carroll's first manuscript, his photographs and Cameron's 1872 photographic series. After all, they all represent Alice Liddell, and depict her physical and natural changes. This physical aspect differs from the fictional metamorphosis of her literary doppelgänger from Wonderland, the main focus of this paper. Tenniel's visual interpretations are secondary to Carroll's, but due to the popularity of the first edition, they become the best known visual icons of Alice: a young blond/ golden girl.

Carroll was no different from most of the photographers of his time, who created a pictorial Romanticism. In Carroll's view, the pictorial dream-like atmosphere which serves as a tabula rasa - is more important than a pre-Darwinian realistic attitude (Green-Lewis 1996: 67). As a result, only Carroll's literary work unravels the adventure of establishing feminine knowledge, while his photographic work is based on common themes. Cameron's representations of women are powerful. By choosing a model as celebrated as Alice Liddell, and by representing her as an empowered Roman Goddess, Cameron exposes the hidden Victorian ambiguity towards Alice, a little girl lost in a strange land, in a territory of brave men. Cameron completes Alice's transformation from golden girl into a powerful, selfconscious, sensual women: Pomona, Ceres, and Alethea, and finally as herself, Alice Liddell. But by presenting her as a sensual subject, Cameron re-located her in the Victorian masculine reality. It seems that there is no ultimate Alice, since this cultural heroine was created for Carroll's literary world, but its muse, the real-world Liddell, presents the process of symbolic growing-up from Carroll's to Cameron's photographic works. In literature, illustration and photography, Alice changes from 
passive to active, from an abnormal size to proportional, from questioning the world to answering it.

The 1865 edition of Alice's Adventures in Wonderland seems to be the reference point for all Alice imagery. But as in a caterpillar's life cycle, the 1865 imagery is just a temporary phase, which tends to develop to the "right size", as we are assured in Chapter One: "her face brightened up at the thought that she was now at the right size" (Carroll 1970: 31-32). The developing Alice never adapts or reconciles with the given situation; she always seeks to evolve, to learn, to know. Hence, she is a proper little Victorian girl, although she often fits Victorian visual and literary attributes. Cameron succeeds in presenting Alice's physical growth as the end of the process that began in Wonderland. By presenting her as a Goddess, this growing process reaches its closure. The metamorphosis that started with Carroll's The Beggar Maid (1858), with Liddell as a Romantic model, completes its cycle in 1872 when Cameron titles one of her portraits - Alice.

\section{References}

\section{Primary Sources}

Cameron, Julia Margaret. Sept. 1872. Pomona (Alice Liddell) (Photograph). 36.3 x $26.3 \mathrm{~cm}$. The J. Paul Getty Museum, Los Angeles.

Cameron, Julia Margaret. Sept. 1872. Alice (Alice Liddell) (Photograph). 28.4 x $10.7 \mathrm{~cm}$. Leonard/Peil Collection, Hans P. Kraus, Jr., Inc., New York.

Carroll, Lewis. 1858. The Beggar Maid (Photograph). 16.3 x $10.9 \mathrm{~cm}$. Albumen silver print from glass negative, The Metropolitan Museum, New York. $<$ http://www.metmuseum. org/collection/the-collection-online/search/283092> (accessed December 3, 2014).

Carroll, Lewis. 1864. "Alice's Adventures Under Ground" (Manuscript and illustrations). The British Library, London. <http://www.bl.uk/collection-items/alices-adventuresunder-ground-the-original-manuscript-version-of-alices-adventures-in-wonderland $>$ (accessed December 3, 2014).

Carroll, Lewis. 1970. "Alice's Adventures in Wonderland." In The Annotated Alice. Introduction and notes by Martin Gardner. Illustrations by John Tenniel. London: Penguin Books.

\section{Secondary Sources}

Alexander, James R. 2006. "Sentiment and Aesthetics in Victorian Photography: The Child Portraits of C.L. Dodgson." The Carrollinian: The Lewis Carroll Journal 17: 2-68.

Armstrong, Nancy. 2002. Fiction in the Age of Photography: The Legacy of British Realism. Cambridge and London: Harvard University Press.

Braman, Joan. 2015. "Introduction." In Di Avantures fun Alis in Vunderland by Lewis Carroll, translated into Yiddish by Joan Braman, i - vii. Portlaoise: Evertype.

Brooker, Will. 2004. Alice's Adventure: Lewis Carroll and Alice in Popular Culture. New York: Continuum Books.

Casteras, Susan P. 2012 (1992). "Excluding Women: The Cult of the Male Genius in Victorian Painting." In Rewriting the Victorians: Theory, History and the Politics of Gender, edited by Linda M. Shires, 116-146. Oxford and New York: Routledge. 
Coar, Lisa. 2012. "Sugar and Spice and All Things Nice: The Victorian Women's AllConsuming Predicament." Victorian Network 4 (1): 48-72.

Cohen, Morton N. \& Edward Wakeling, eds. 2003. Lewis Carroll and His Illustrators: Collaborations \& Correspondence, 1865-1898. Cornell: Cornell University Press.

Cox, Julian. 2002. "Introduction." In Julia Margaret Cameron: Photographs from the J. Paul Getty Museum, 5-8. Los Angeles: J. Paul Getty Museum.

Cox, Julian \& Colin Ford. 2003. Julia Margaret Cameron: The Complete Photographs. Los Angeles: J. Paul Getty Museum.

Deleuze, Gilles. 1969. Logique du Sens. Paris: Editions de Minuit.

Driscoll, Catherine. 2002. Girls: Feminine Adolescence in Popular Culture and Cultural Theory. New York: Columbia University Press.

Ford, Collin. 2003. Julia Margaret Cameron: A Critical Biography. Los Angeles: Getty Publications.

Gilbert, Sandra M. \& Susan Gubar. 2000. The Woman in the Attic: the Woman Writer and the Nineteenth Century Literature Imagination. $2^{\text {nd }}$ edn. New Haven and London: Yale University Press, Yale Nota Bene.

Golden, Catherine J. 2003. The Image of the Woman Reader in British and American Fiction. Gainesville: University Press of Florida.

Green-Lewis, Jennifer. 1996. Framing the Victorian: Photography and the Culture of Realism. Cornell: Cornell University Press.

Hancher, Michael. 1985. The Tenniel Illustrations to the "Alice” Books. Ohio: Ohio State University Press.

Heller, Erga. 2014. "When Fantasy Became a Real Issue: On Local and Global Aspects of Literary Translation/Adaptation, Subtitling and Dubbing Films for the Young." In Media and Translation: An Interdisciplinary Approach, edited by D. Abend-David, 173-194. New York and London: Bloomsbury Academic.

Manning, Kara M. 2011. “That Effect of Living Backwards': Technological Change, Lewis Carroll's Alice Books, and Tim Burton's Alice in Wonderland." Neo-Victorian Studies 4 (2): 154-179.

Marsh, Anne. 2003. The Dark Room: Photography and the Theatre of Desire. Victoria: Macmillan Australia.

Meier, Franz. 2009. "Photographic Wonderland: Intermediality and Identity in Lewis Carroll's Alice Books." In Alice Beyond Wonderland: Essays for the Twenty First Century, edited by Cristopher Hollingsworth, 117-134. Iowa: University of Iowa Press.

Ofek, Galia. 2009. Representations of Hair in Victorian Literature and Culture. Farnham and Burlington: Ashgate.

Pereira, Nilce M. 2008. "Book Illustration as (Intersemiotic) Translation: Pictures Translating Words." Meta 53 (1): 104-119.

Robson, Catherine. 2001. Men in Wonderland: The Lost Girlhood of the Victorian Gentleman. Princeton: Princeton University Press.

Sandner, David. 1996. The Fantastic Sublime: Romanticism and Transcendence in the Nineteenth-Century Children's Fantasy Literature. Westport: Greenwood Press.

Spence, Cathryn. 2013. "Liddell, Alice Pleasance." In Dictionary of Artists'Models, edited by Jill Berk Jiminez, 323-326. New York: Routledge.

Steedman, Carolyn. 1998. Strange Dislocations: Childhood and the Idea of Human Interiority, 1780-1930. Cambridge: Harvard University Press.

Williams, James. 2008. Gilles Deleuze's Logic of Sense: A Critical Introduction and Guide. Edinburgh: Edinburgh University Press.

Winchester, Simon. 2011. The Alice Behind Wonderland. Oxford: Oxford University Press. 


\section{Erga Heller}

Učiteljski fakultet Kaye, Be'er Sheba, Izrael

Fakultät für Lehrerbildung Kaye, Be'er Sheba (Israel)

\section{Od djevojčice s ulice do rimske božice: stvaranje višestrukih vizualnih Alica od 1858. do 1872.}

Viktorijanske prikaze djetinjstva nalazimo u raznolikim kulturnim tekstovima, $\mathrm{i}$ to $\mathrm{u}$ različitim verbalnim i vizualnim oblicima - od književnih opisa do samostalnih slika. Aličine pustolovine u Čudozemskoj Lewisa Carrolla (1865.) u tome smislu ne predstavljaju iznimku. Međutim, Aličin lik jedan je od prvih koji se prometnuo u intermedijsku figuru, pri čemu je Alica postala junakinjom fantastične književnosti kao i ikonom popularne kulture. Ovaj se rad usmjerava na tri oblika Aličina umjetničkoga prikaza: (a) verbalni Lewisa Carrolla, (b) fotografske otiske ,prave“ Alice, Alice Liddell, koje su načinili Carroll, 1858. godine, i Julia Margaret Cameron, 1872. godine, kao i na (c) ilustracije Lewisa Carrolla (1864.) i Johna Tenniela (1865.). Istražujući višestruke Aličine prikaze u odabranome korpusu, cilj je rada utvrditi je li Carrollova junakinja ikada bila „prava“ viktorijanska djevojčica. Nadalje, u radu se analiziraju Aličine vizualne karakteristike u svrhu razotkrivanja Alice kao onodobnoga vizualnoga koncepta.

Ključne riječi: fantastična književnost, Aličine pustolovine u Zemlji Čudesa, ilustracija, fotografija, intermedijalnost, vizualna kultura, Julia Margaret Cameron.

\section{Vom Straßenmädchen bis hin zur römischen Göttin: Entstehung zahlreicher visueller Alice-Gestalten im Zeitraum von 1858 bis 1872}

Viktorianische Kindheitsdarstellungen sind in diversen kulturellen Texten vorzufinden, und zwar im Rahmen unterschiedlicher verbaler und visueller Darstellungsformen - von literarischen Beschreibungen bis hin zu autonomen Bildern. Das Werk von Lewis Carroll Alice im Wunderland (1865) stellt in diesem Sinne keine Ausnahme dar. Dennoch ist Alice eine der ersten Gestalten, die sich zu einer intermedialen Figur entwickelte, um dabei sowohl zur Heldin der fantastischen Literatur als auch zur Ikone der Popkultur zu werden. Im Beitrag werden drei Formen der künstlerischen Darstellung von Alice besprochen: (a) die verbale Form von Lewis Carroll, (b) die fotografischen Abbildungen der ,wahren Alice, Alice Liddell, die Carroll 1858 und Julia Margaret Cameron 1872 hergestellt haben, sowie (c) die Illustrationen von Lewis Carroll (1864) und John Tenniel (1865). Anhand der Auseinandersetzung mit der mehrfachen Darstellung von Alice im Rahmen des oben angeführten Korpus möchte man feststellen, ob Carrolls Heldin jemals ein ,echtes ${ }^{*}$ viktorianisches Mädchen war. Darüber hinaus werden im Beitrag auch die visuellen Merkmale der Alice-Gestalt analysiert, um Alice als ein aus jener Zeit stammendes visuelles Konzept darzustellen.

Schlüsselwörter: fantastische Literatur, Alice im Wunderland, Illustration, Fotografie, Intermedialität, visuelle Kultur, Julia Margaret Cameron 